\title{
Heavy-Metal Concentrations in Small Mammals from a Diffusely Polluted Floodplain: Importance of Species- and Location-Specific Characteristics
}

\author{
S. Wijnhoven, ${ }^{1,8}$ R. S. E. W. Leuven, ${ }^{2}$ G. van der Velde, ${ }^{3,4}$ G. Jungheim, ${ }^{2}$ E. I. Koelemij, ${ }^{2}$ F. T. de Vries, ${ }^{2,5}$ \\ H. J. P. Eijsackers, ${ }^{5,6}$ A. J. M. Smits ${ }^{1,7}$ \\ ${ }^{1}$ Centre for Sustainable Management of Resources, Institute for Science, Innovation and Society, Radboud University Nijmegen, P. O. Box 9010, \\ NL-6500 GL Nijmegen, The Netherlands \\ ${ }^{2}$ Department of Environmental Science, Institute for Wetland and Water Research, Radboud University Nijmegen, P. O. Box 9010, \\ NL-6500 GL Nijmegen, The Netherlands \\ ${ }^{3}$ Department of Animal Ecology and Ecophysiology, Institute for Wetland and Water Research, Radboud University Nijmegen, P. O. Box 9010, NL-6500 \\ GL Nijmegen, The Netherlands \\ ${ }^{4}$ National Museum of Natural History Naturalis, P. O. Box 9517, 2300 RA Leiden, The Netherlands \\ ${ }^{5}$ Wageningen University and Research Centre, P. O. Box 9101, NL-6700 HB Wageningen, The Netherlands \\ ${ }^{6}$ Institute of Ecological Science, Vrije Universiteit Amsterdam, De Boelelaan 1085, NL-1081 HV Amsterdam, The Netherlands \\ ${ }^{7}$ Water Management and Sustainability, Faculty of Social Sciences, Erasmus University Rotterdam, P. O. Box 1738, NL-3000 DR Rotterdam, \\ The Netherlands \\ ${ }^{8}$ Monitor Taskforce, Netherlands Institute of Ecology-Centre for Estuarine and Marine Ecology, P. O. Box 140, 4400 AC Yerseke, The Netherlands
}

Received: 21 June 2006/Accepted: 5 November 2006

\begin{abstract}
The soil of several floodplain areas along large European rivers shows increased levels of heavy metals as a relict from past sedimentation of contaminants. These levels may pose risks of accumulation in food webs and toxicologic effects on flora and fauna. However, for floodplains, data on heavy-metal concentrations in vertebrates are scarce. Moreover, these environments are characterised by periodical flooding cycles influencing ecologic processes and patterns. To investigate whether the suggested differences in accumulation risks for insectivores and carnivores, omnivores, and herbivores are reflected in the actual heavy-metal concentrations in the species, we measured the current levels of $\mathrm{Zn}, \mathrm{Cu}$, $\mathrm{Pb}$, and $\mathrm{Cd}$ in 199 specimens of 7 small mammal species (voles, mice, and shrews) and in their habitats in a diffusely polluted floodplain. The highest metal concentrations were found in the insectivorous and carnivorous shrew, Sorex araneus. Significant differences between the other shrew species, Crocidura russula, and the vole and mouse species was only found for $\mathrm{Cd}$. The $\mathrm{Cu}$ concentration in Clethrionomys glareolus, however, was significantly higher than in several other vole and mouse species. To explain the metal concentrations found in the specimens, we related them to environmental variables at the trapping locations and to certain characteristics of the mammals. Variables taken into account were soil total and $\mathrm{CaCl}_{2}$-extractable metal concentrations at the trapping locations; whether locations were flooded or nonflooded; the trapping season; and the life stage; sex; and fresh weight of the specimens. Correlations between body and soil concentrations and location or specimen characteristics
\end{abstract}

Correspondence to: S. Wijnhoven; email: s.wijnhoven@nioo.knaw.nl were weak. Therefore; we assumed that exposure of small mammals to heavy-metal contamination in floodplains is significantly influenced by exposure time, which is age related, as well as by dispersal and changes in foraging and feeding patterns under influence of periodic flooding.

Industrial and communal wastewater discharges and agricultural activities have caused large-scale soil contamination of a majority of the floodplains along the large European rivers (Nienhuis et al. 1998). The heavy metals $\mathrm{Cd}, \mathrm{Cu}, \mathrm{Pb}$, and $\mathrm{Zn}$ are present in large amounts in these diffusely polluted floodplains (Middelkoop \& Van Haselen 1999; Vink et al. 1999). Several studies have suggested that the present contaminant levels pose risks to floodplain ecosystems through accumulation of heavy metals in food webs and possible toxicologic effects in a variety of species (Hendriks et al. 1995; Van den Brink et al. 2003; Kooistra et al. 2001, 2005; Leuven et al. 2005).

Studies of contaminant levels in floodplain species have been scarce and generally focused on lower trophic levels, such as vegetation (Schröder 2005), and macro-invertebrates, such as earthworms, snails, spiders, and insects (Hobbelen et al. 2004; Notten et al. 2005; Van Vliet et al. 2005). Exceptions are studies including the common shrew Sorex araneus (Hendriks et al. 1995), the little owl Athene noctua vidalli (Van den Brink et al. 2003), and the badger Meles meles, which were expected to forage in floodplains (Van den Brink \& Ma 1998). Assessments of the risk of contaminant accumulation in vertebrates (e.g., mammals and birds) in floodplains have generally been based on soil contaminant levels combined with accumulation 
factors, consumption rates, and life expectancies (Jongbloed et al. 1996; Pascoe et al. 1996; Kooistra et al. 2001, 2005). Except for the soil contaminant levels, these parameters for the calculation of accumulation risks are generally derived from literature data from inland area or laboratory studies. However, floodplains are highly dynamic environments, with periodical flooding affecting species distribution, life expectancy and mortality, habitat suitability patterns within the landscape, food availability, and recolonisation processes from the nonflooded areas (Robinson et al. 2002; Klok et al. 2006; Wijnhoven et al. 2006).

Small mammals (voles, mice, and shrews) play an important role in floodplain food webs by acting at different trophic levels. They include predominantly herbivorous as well as insectivorous and carnivorous species. They are prey to a whole range of predatory mammals and birds of prey (Erlinge et al. 1983; Jongbloed et al. 1996). Because these smallmammal species can be numerous in certain areas within the floodplains and are often mentioned as species at risk of toxicologic effects of the current contaminant levels in floodplains themselves, they are suitable as monitors of contaminant levels in floodplain ecosystems. It has been shown that the distribution and densities of the common small-mammal species are highly influenced by flooding events, resulting in the highest densities throughout the year occurring on and near the nonflooded areas (Wijnhoven et al. 2005, 2006). Densities were also found to be much higher at the end of summer and in autumn compared with winter and spring. This is a result of the gradual population growth after increased mortality in winter, especially during floods, which is reflected in the age distribution. Total metal concentrations in the soil are generally higher in the lower, frequently flooded areas than in the nonflooded areas, but $\mathrm{CaCl}_{2}$-extractable concentrations do not show a similar pattern (Wijnhoven et al. 2006). It is assumed that metal concentrations in small mammals are reflected not only by trophic level but also by exposure time and metal concentrations in the exposure areas (Hunter et al. 1989; Torres \& Johnson 2001). Furthermore, different contaminant levels in small-mammal species can occur because of seasonal variation (Greville \& Morgan 1989; Ma et al. 1991) as well as differences in size and sex (Dodds-Smith et al. 1992; DamekPoprawa \& Sawicka-Kapusta 2004). We hypothesized that of the seven common small mammal species in our research area (Wijnhoven et al. 2005), the highest average metal concentrations would be found in the insectivores and carnivores, (e.g., common shrew Sorex araneus and white-toothed shrew Crocidura russula), whereas the lowest ones were expected in predominantly herbivorous species (e.g., common vole Microtus arvalis, short-tailed field vole Microtus agrestis, wood mouse Apodemus sylvaticus, and harvest mouse Micromys minutus), with the more omnivorous bank vole Clethrionomys glareolus in between. Species-specific metal concentrations were expected to be positively related to the metal concentrations in the soil of the trapping locations. We investigated whether these patterns of species- and locationrelated body metal concentrations were present in a diffusely polluted floodplain. The study tried to answer the following research questions: (1) Are there differences in average metal concentrations between species, and can these differences be explained by feeding behaviour (herbivory, omnivory, and/or insectivory and carnivory)? (2) Are such differences in metal concentration between species similar for each of the investigated metals? (3) Are the possible interspecific and intraspecific differences in body metal concentrations related to soil metal concentrations or $\mathrm{CaCl}_{2}$-extractable concentrations at the trapping locations? (4) Are there intraspecific differences in metal concentrations that may be related to sex, life stage or size of the animals, the time of the year, or the positioning the traps? The article discusses the consequences of our findings for heavy-metal exposure and accumulation risks in floodplain food webs.

\section{Materials and Methods}

\section{Data Collection}

All data were collected at the Afferdensche en Deestsche Waarden (ADW), a moderately to heavily polluted embanked floodplain area along the river Waal, the main distributary of the Rhine in The Netherlands (Fig. 1). The research area consists of lands inside and outside the summer dikes. The summer dikes are the lower inner embankments protecting agricultural areas in the floodplain against summer floods. Large parts of the floodplain are periodically flooded, on average once a year, predominantly in winter. The floodplain includes areas with and without agricultural activities. Those without agriculture, feature naturally developed vegetation and offer a wide range of habitats. Detailed descriptions of the research area are given in Wijnhoven et al. $(2005,2006)$.

Small mammals from the ADW floodplain were collected at 58 sites (Fig. 1) between 2001 and 2003 using Longworth live traps in lines of 5 to 10 traps at each site. The traps were baited with apple, carrot, and rinsed meat and were stuffed with hay and tissue. Specifically for this study, there were three sessions of two 3-day trapping trials, all traps were checked twice a day in August 2002 and again in June and October 2003. Furthermore, all trapping casualties from monitoring studies were included, especially specimens trapped in winter and spring because mortality in that time of the year is higher (Wijnhoven et al. 2005, 2006). Trapping locations were originally selected to monitor recolonisation of the floodplain after flood events (Wijnhoven et al. 2005), so they were chosen based on habitat characteristics (vegetation structure, soil type, and management type) without previous information on the levels of contamination. Therefore, trapping sites covered the whole range from nonflooded parts to flooded locations situated far from the nonflooded areas, and were expected to show a representative variation in contaminant levels for the study area. At each of the sites, three soil cores, prepared from three or five soil samples from a $1 \mathrm{~m}^{2}$ plot, were taken with line intervals of at least $10 \mathrm{~m}$. A 5-g portion of soil from each sample was oven dried for 24 hours at $105^{\circ} \mathrm{C}$. The total metal content of $0.2 \mathrm{mg}$ dry weight (DW) substrate in a mixture of $3.0 \mathrm{ml} 65 \% \mathrm{HNO}_{3}$ and $1.5 \mathrm{ml}$ $37 \% \mathrm{HCl}$ was measured after microwave destruction using a MLS1200 MEGA microwave oven (Milestone, Sorisole, Italy). The samples were topped up to $50 \mathrm{ml}$, after which the metal content was measured using inductively coupled plasma-atomic emission spectrometry (ICP-AES; Spectro Analytical Instruments, Kleve, Germany). The $0.01 \mathrm{M} \mathrm{CaCl}_{2}$-exchangeable fraction was determined as a measure of the potential metal solubility. A 6-g fresh-weight portion of substrate, to which $0.01 \mathrm{M} \mathrm{CaCl}_{2}$ had been added in a 1:10 (m[DW]/v) ratio, was mixed for 2 hours, after which the suspension was centrifuged at 12,000 rpm $(5,000 x \mathrm{~g})$ for 15 minutes. After the $\mathrm{pH}_{\mathrm{CaCl} 2}$ had been measured in the substrate suspension in $0.01 \mathrm{M} \mathrm{CaCl}_{2}$, the supernatant was filtered over a $0.45-\mu \mathrm{m}$ pore filter. $\mathrm{A} \mathrm{pH}$ of 2 was obtained by adding a few droplets of $65 \% \mathrm{HNO}_{3}$, and the metal content of the sample was subsequently measured on the spectrometer. 

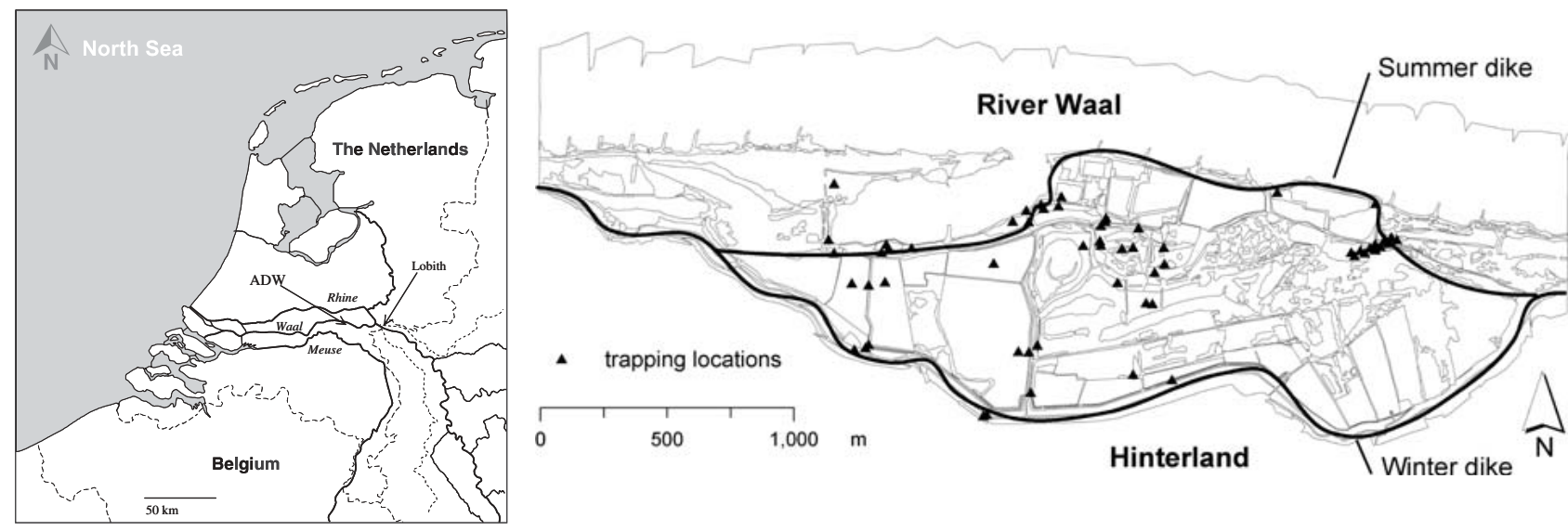

Fig. 1. Location of the ADW floodplain area in The Netherlands and positions of the trapping locations (with 5 to 10 traps each) within the floodplain

Fresh weights (FWs) of the mammals were determined, and the liver and kidneys of each specimen were weighed (FW). Parts of these organs and flank muscles were oven dried for 24 hours at $105^{\circ} \mathrm{C}$, after which DWs were measured. The metal contents of the animal tissues were measured after microwave extraction of approximately 0.01 to $0.25 \mathrm{mg} \mathrm{DW}$ with $\mathrm{HNO}_{3}$ and $\mathrm{HCl}$ and analysed using ICP-AES as described previously. The metal concentrations in whole animals were calculated from the concentrations in the liver, kidneys, and muscle tissue. Concentrations in muscle tissue were assumed to reflect the concentration in the animal's remaining tissues, i.e., the entire animal minus liver and kidneys. Calculations were based on the speciesspecific weighed average distributions in percentage DW for liver, kidneys, and other tissues (tissue-to-total body ratios) and the tissuespecific DW-to-FW ratios derived from our own data.

\section{Statistical Analysis}

Interspecific differences in metal concentration distributions were statistically tested at $P<0.05$ using the two-sample KolmogorovSmirnov test (KS test) in Systat for Windows 11 (Systat Software Inc., Richmond, CA, USA) because the metal content values within the species did not show a normal distribution (per one-sample KS test). To search for possible explanations for interspecific differences in metal concentrations, metal concentrations in the soil (average total and $\mathrm{CaCl}_{2}$-extractable concentrations at the locations where individuals were trapped) were also compared with the two-sample KS test. Two-sample KS tests are used because concentration distribution variation ("shape") and average or median concentration distribution ("location") will affect exposure of populations (Sokal \& Rohlf 1995). To calculate functional relations of metal concentrations in species, regressions between metal concentrations and mammal characteristics and environmental factors were calculated making use of Microsoft Office Excel 2003 (Microsoft Corporation, Redmond, WA, USA), according to the stepwise-method, with a critical $F$ value for the regression equations calculated at $P<0.05$. A significance level of $P<0.05$ for the individual regression coefficients was used. Parameters included were the total and $\mathrm{CaCl}_{2}$-extractable metal concentrations at the trapping sites; the trapping locations in either flooded or nonflooded areas; the trapping times (for which the dates were divided into the four seasons); and the sexes (male $v s$. female), life stages (juvenile $v s$. adult); and sizes and conditions of the animals (recorded as $\mathrm{mg}$ FW). Data of specimens were only included if all of the information for the selected parameters was available, which means that the sample size in these analyses was sometimes slightly smaller than the total number of specimens collected. Similarity in sex ratio for each of the species and the numbers of a species trapped in flooded and nonflooded areas was tested with the binomial test (with a two-tailed significance level of 5\%) (Sokal \& Rohlf 1995). Interspecific differences in the distribution of DW-toFW ratios, organ-to-total body ratios, sex ratio, and life-stage composition of the populations, as well as the proportional distribution of the populations over the flooded and nonflooded areas and the numbers trapped in each season, were also tested in Systat 11 (two-sample KS test) after checking for possible normal distributions (one-sample KS test).

\section{Results}

\section{Differences in Heavy-Metal Concentrations Between Species}

In total, 199 specimens of 7 small-mammal species were collected (Table 1). The variance in organ-to-total body ratio within the species groups was not large, with the exception of $S$. araneus (Table 2). Comparing these ratios between species, the two shrew species showed heavier livers and kidneys than the other species. Distributions in DW-to-FW ratios of especially liver, but also muscle tissue, also differed between species. Differences for this ratio in kidneys were found only between $A$. sylvaticus and M. agrestis. In all species, the DWto-FW ratios were somewhat higher for livers than for kidneys and lowest for muscle tissue.

The average whole-body $\mathrm{Zn}$ concentration was highest in $S$. araneus with $126 \mathrm{mg} \mathrm{kg}-1$ DW, followed in descending order by $C$. glareolus, C. russula, A. sylvaticus, M. arvalis, M. agrestis, and M. minutus (Fig. 2). The differences between $S$. araneus and $M$. arvalis, between $S$. araneus and A. sylvaticus and between $S$. araneus and $C$. glareolus were significant $(P<0.05)$. The variation in $\mathrm{Zn}$ concentrations in $S$. araneus was large. The highest $\mathrm{Zn}$ concentration was, however, observed in a specimen of $C$. glareolus, which contained $866 \mathrm{mg} \mathrm{kg}^{-1} \mathrm{DW}$, more than twice as much as the highest concentration measured in a specimen of $S$. araneus (416 $\mathrm{mg} \mathrm{kg}^{-1} \mathrm{DW}$ ). 
Table 1. Characteristics of the small mammals collected

\begin{tabular}{|c|c|c|c|c|c|c|c|c|}
\hline Species & $N$ & $\mathrm{FW}_{\text {body }}(\mathrm{g})$ & Sex ratio & & Life stage & Flooding & & Season \\
\hline Apodemus sylvaticus & 21 & $16.06 \pm 2.42$ & $1.30 \pm 0.47$ & More male animals & $1.52 \pm 0.51$ & $1.33 \pm 0.48^{\mathrm{a}}$ & NS & $2.95 \pm 0.50^{\mathrm{a}}$ \\
\hline Clethrionomys glareolus & 56 & $19.68 \pm 4.62$ & $1.55 \pm 0.50$ & NS & $1.68 \pm 0.47$ & $1.79 \pm 0.41^{\mathrm{b}}$ & More nonflooded & $2.32 \pm 0.64^{\mathrm{bd}}$ \\
\hline Crocidura russula & 11 & $10.97 \pm 1.04$ & $1.45 \pm 0.52$ & NS & 2 & $1^{\mathrm{ac}}$ & More flooded & $2.82 \pm 0.40^{\mathrm{ab}}$ \\
\hline Microtus agrestis & 9 & $21.58 \pm 8.72$ & $1.33 \pm 0.50$ & NS & $1.67 \pm 0.50$ & $2^{\text {bde }}$ & More nonflooded & $2.44 \pm 0.53^{b c}$ \\
\hline Microtus arvalis & 31 & $19.48 \pm 6.03$ & $1.55 \pm 0.51$ & NS & $1.71 \pm 0.46$ & $1.06 \pm 0.25^{\mathrm{cf}}$ & More flooded & $2.61 \pm 0.50^{b}$ \\
\hline Micromys minutus & 4 & $4.53 \pm 0.18$ & 1 & NS & 2 & $1^{\text {adf }}$ & NS & $3^{\mathrm{ab}}$ \\
\hline Sorex araneus & 67 & $8.32 \pm 2.07$ & $1.45 \pm 0.50$ & NS & $1.66 \pm 0.48$ & $1.55 \pm 0.50^{\mathrm{ae}}$ & NS & $2.18 \pm 0.85^{\mathrm{cd}}$ \\
\hline
\end{tabular}

${ }^{a}$ The numbers per species are shown with average values $( \pm \mathrm{SD})$ of fresh weights' sex ratios $(1=$ male; $2=$ female $)$, life stages $(1=$ juvenile; $2=$ adult $)$, trapping locations $(1=$ flooded; $2=$ nonflooded $)$ and trapping seasons $(1=$ spring; $2=$ summer; $3=$ autumn; $4=$ winter $)$. Unequal intraspecies distributions of sex ratio and flooding were tested $(P<0.05)$ using binomial test (indicated when unequal; NS $=$ no significant unequal distribution). Interspecies differences were tested when relevant using the two-sample Kolmogorov-Smirnov test $(P<0.05)$; significant differences are indicated by different superscript letters.

Table 2. Species and tissue-specific DW to FW ratios ( \pm SD) and species-specific tissue-to-total body ratios ( \pm SD) based on DWs used to calculate whole-body metal concentrations of specimens

\begin{tabular}{|c|c|c|c|c|c|c|c|}
\hline \multirow[t]{2}{*}{ Species } & \multirow[t]{2}{*}{$N$} & \multicolumn{3}{|l|}{ DW-to-FW ratio } & \multicolumn{3}{|c|}{ Tissue-to-total body ratio (in DW) } \\
\hline & & Liver & Kidney & Muscle & Liver & Kidney & Remaining tissue \\
\hline A. sylvaticus & 21 & $0.316 \pm 0.057^{\mathrm{ac}}$ & $0.253 \pm 0.027^{\mathrm{a}}$ & $0.235 \pm 0.057^{\mathrm{a}}$ & $0.0648 \pm 0.0103^{\mathrm{a}}$ & $0.0152 \pm 0.0027^{\mathrm{a}}$ & $0.920 \pm 0.011^{\mathrm{a}}$ \\
\hline C. glareolus & 56 & $0.272 \pm 0.081^{\mathrm{b}}$ & $0.243 \pm 0.043^{\mathrm{ab}}$ & $0.218 \pm 0.066^{\mathrm{c}}$ & $0.0701 \pm 0.0123^{\mathrm{a}}$ & $0.0165 \pm 0.0029^{\mathrm{a}}$ & $0.913 \pm 0.014^{\mathrm{c}}$ \\
\hline C. russula & 11 & $0.315 \pm 0.041^{\mathrm{a}}$ & $0.246 \pm 0.022^{\mathrm{ab}}$ & $0.204 \pm 0.056^{\mathrm{abc}}$ & $0.0904 \pm 0.0191^{\mathrm{b}}$ & $0.0213 \pm 0.0031^{\mathrm{b}}$ & $0.888 \pm 0.021^{\mathrm{b}}$ \\
\hline M. agrestis & 9 & $0.251 \pm 0.038^{\mathrm{b}}$ & $0.228 \pm 0.034^{\mathrm{b}}$ & $0.210 \pm 0.044^{\mathrm{abc}}$ & $0.0701 \pm 0.0115^{\mathrm{a}}$ & $0.0149 \pm 0.0027^{\mathrm{ac}}$ & $0.915 \pm 0.012^{\mathrm{ac}}$ \\
\hline M. arvalis & 31 & $0.287 \pm 0.034^{\mathrm{cd}}$ & $0.253 \pm 0.029^{\mathrm{ab}}$ & $0.235 \pm 0.033^{\mathrm{ac}}$ & $0.0678 \pm 0.0097^{\mathrm{a}}$ & $0.0127 \pm 0.0013^{\mathrm{c}}$ & $0.919 \pm 0.010^{\mathrm{ac}}$ \\
\hline M. minutus & 4 & $0.264 \pm 0.012^{\mathrm{bd}}$ & $0.244 \pm 0.032^{\mathrm{ab}}$ & $0.173 \pm 0.088^{\mathrm{abc}}$ & $0.0679 \pm 0.0104^{\mathrm{a}}$ & $0.0250 \pm 0.0060^{\mathrm{b}}$ & $0.907 \pm 0.014^{\mathrm{abc}}$ \\
\hline S. araneus & 67 & $0.305 \pm 0.056^{\mathrm{ad}}$ & $0.239 \pm 0.046^{\mathrm{ab}}$ & $0.178 \pm 0.072^{\mathrm{b}}$ & $0.106 \pm 0.084^{\mathrm{b}}$ & $0.0241 \pm 0.0239^{\mathrm{b}}$ & $0.869 \pm 0.107^{\mathrm{b}}$ \\
\hline
\end{tabular}

${ }^{a}$ Interspecies differences were tested using the two-sample Kolmogorov-Smirnov test $(P<0.05)$; significant differences are indicated by different superscript letters

Average $\mathrm{Cu}$ concentrations were also highest in $S$. araneus, followed in descending order by $M$. arvalis, C. glareolus, C. russula, M. minutus, A. sylvaticus, and (lowest) M. agrestis. The average of $15.6 \mathrm{mg} \mathrm{kg} \mathrm{DW}^{-1} \mathrm{DW}$. araneus was significantly higher than in all other species except $C$. russula and M. minutus. The average $\mathrm{Cu}$ concentration of $6.71 \mathrm{mg} \mathrm{kg} \mathrm{m}^{-1}$ DW in $C$. glareolus was also significantly higher than those found in A. sylvaticus and M. agrestis, with 4.05 and $3.38 \mathrm{mg}$ $\mathrm{kg}^{-1} \mathrm{DW}$, respectively. The highest $\mathrm{Cu}$ concentration was measured in a specimen of $S$. araneus, with $88.9 \mathrm{mg} \mathrm{kg}^{-1} \mathrm{DW}$, but an individual of $M$. arvalis also had a high concentration, i.e., $62.0 \mathrm{mg} \mathrm{kg}^{-1} \mathrm{DW}$.

The order from high to low in average $\mathrm{Pb}$ concentrations was $S$. araneus, C. russula, C. glareolus, M. agrestis, M. arvalis, A. sylvaticus, and $M$. minutus. The average value of $32.6 \mathrm{mg} \mathrm{Pb}$ $\mathrm{kg}^{-1} \mathrm{DW}$ in $S$. araneus was significantly higher than the average concentrations in $A$. sylvaticus and $C$. glareolus. For all species, only a few individuals had increased $\mathrm{Pb}$ levels, as was indicated by the median concentration of $<1.60 \mathrm{mg} \mathrm{kg}^{-1} \mathrm{DW}$ for all species. The highest concentrations in individuals were found in C. glareolus (270 $\mathrm{mg} \mathrm{Pb} \mathrm{kg}^{-1}$ ) and S. araneus $\left(264 \mathrm{mg} \mathrm{Pb} \mathrm{kg}^{-1}\right)$.

The average $\mathrm{Cd}$ concentration was significantly higher in $M$. agrestis than in $S$. araneus, $C$. russula, and M. arvalis; however, this is largely the result of one individual, which contained $63.9 \mathrm{mg} \mathrm{Cd} \mathrm{kg}^{-1} \mathrm{DW}$. The average $\mathrm{Cd}$ concentration of $3.49 \mathrm{mg} \mathrm{kg}^{-1}$ in $S$. araneus was significantly higher than the average concentrations in all other species except $C$. russula. The median concentrations were highest in $S$. araneus, with
$1.82 \mathrm{mg} \mathrm{Cd} \mathrm{kg}^{-1} \mathrm{DW}$, followed by C. russula and M. agrestis, with median concentrations of 0.58 and $0.57 \mathrm{mg} \mathrm{Cd} \mathrm{kg}^{-1} \mathrm{DW}$, respectively, and the other species with median concentrations $<0.20 \mathrm{mg} \mathrm{Cd} \mathrm{kg}^{-1} \mathrm{DW}$.

\section{Exposure of Small Mammals to Heavy Metals}

Exposure of species to total metal concentrations showed similar patterns for each of the metals. The total metal concentrations at the trapping sites of $C$. glareolus and $M$. agrestis were significantly lower than those at the sites of most of the other species, depending on the investigated metal (Fig. 3). Total $\mathrm{Zn}$ concentrations at the trapping locations of A. sylvaticus (398 $\left.\mathrm{mg} \mathrm{kg}^{-1} \mathrm{DW}\right)$, C. russula $(392 \mathrm{mg}$ $\mathrm{kg}^{-1} \mathrm{DW}$ ), and $M$. arvalis $\left(377 \mathrm{mg} \mathrm{kg}^{-1} \mathrm{DW}\right)$ were significantly higher than those at the trapping locations of $C$. glareolus (200 mg kg $\left.{ }^{-1} \mathrm{DW}\right)$ and M. agrestis $\left(110 \mathrm{mg} \mathrm{kg}^{-1}\right.$ DW) and higher at the trapping locations of S. araneus (289 $\mathrm{mg} \mathrm{kg}^{-1} \mathrm{DW}$ ) than at those of $M$. agrestis. For $\mathrm{Cu}$ and $\mathrm{Pb}$, significant differences were found between A. sylvaticus, $M$. arvalis, $S$. araneus, and $C$. russula, all of which had high exposure concentrations, and C. glareolus and $M$. agrestis, which had low exposure concentrations. With regard to $\mathrm{Cd}$, A. sylvaticus and $S$. araneus were exposed to significantly higher concentrations than were $C$. glareolus and $M$. agrestis.

Exposure to $\mathrm{CaCl}_{2}$-extractable $\mathrm{Zn}$ was highest for $M$. agrestis and $C$. glareolus, which is significantly higher than 

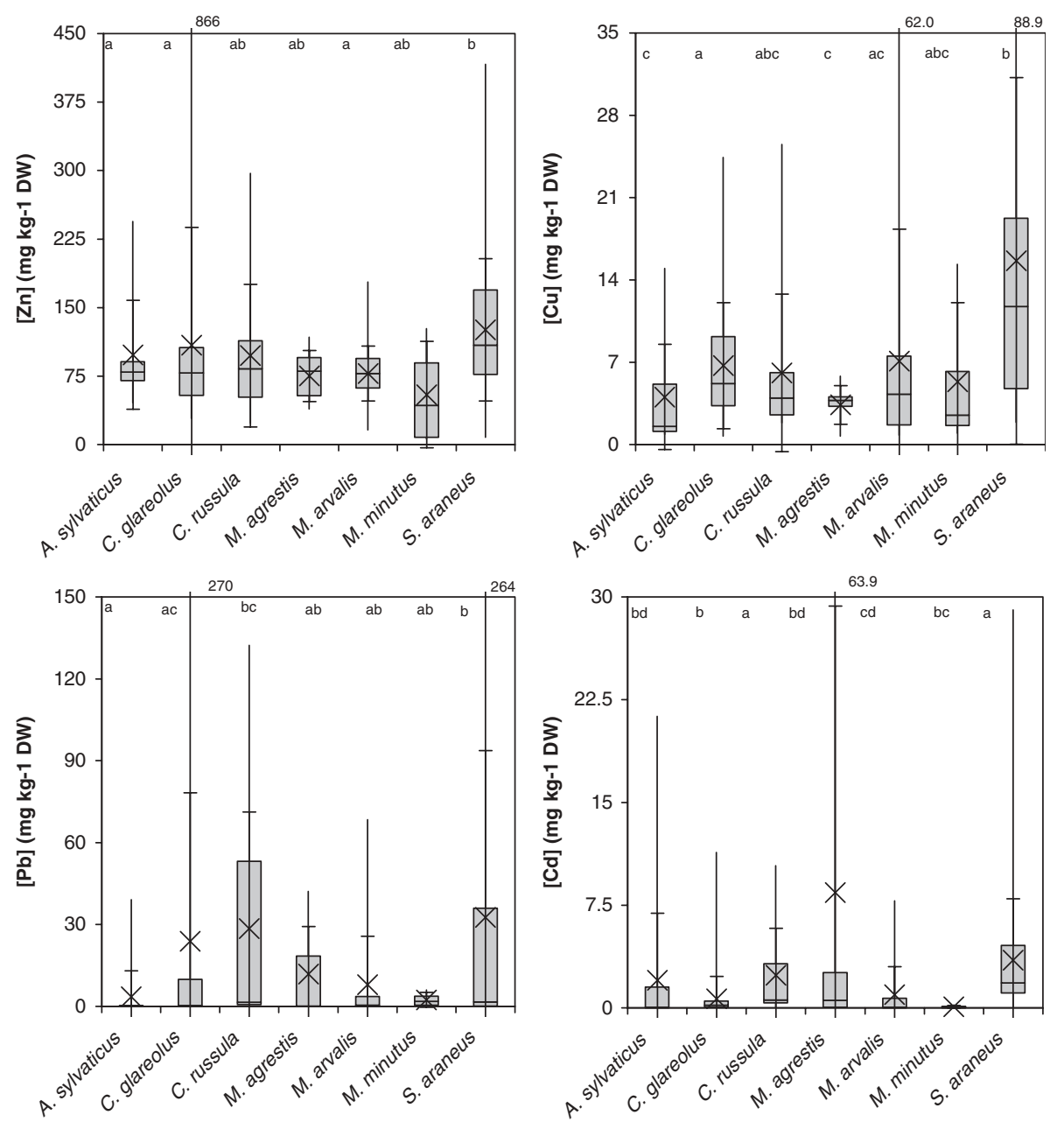

Fig. 2. Metal concentrations in various small-mammal species trapped in the ADW floodplain. Average metal concentrations are indicated by crosses; error bars show SDs; total range (minimum and maximum observations) is shown as a vertical line. The columns indicate the $25 \%$ and $75 \%$ percentiles, with the median in between. Different letters indicate significant differences $(P<0.05)$ in concentration distributions; identical letters indicate no significant differences between species

for the other species (Fig. 3). Of these species, A. sylvaticus was exposed to significantly higher concentrations than M. arvalis, C. russula, and M. minutus. Differences in $\mathrm{CaCl}_{2}-$ extractability of $\mathrm{Cu}$ and $\mathrm{Pb}$ were smaller, but $A$. sylvaticus, C. glareolus, M. arvalis, and S. araneus were exposed to higher $\mathrm{Cu}$ levels than $M$. agrestis, whereas A. sylvaticus, C. glareolus, $M$. arvalis, and $S$. araneus were exposed to higher $\mathrm{Pb}$ levels than $C$. russula and M. agrestis. Exposure to $\mathrm{CaCl}_{2}$-extractable $\mathrm{Cd}$ concentrations was similar for all species.

\section{Regression of Metal Concentrations}

Significant regressions between metal concentrations in the various species on one hand and species characteristics and/or environmental variables on the other hand were found for A. sylvaticus with respect to $\mathrm{Zn}, \mathrm{Cu}$, and $\mathrm{Pb}$, respectively (Table 3). Of the variance in $\mathrm{Zn}$ concentrations in this species, $58 \%$ was explained by the parameters taken into account: season, total $\mathrm{Zn}$ concentration in the soil, locations being flooded or nonflooded, and $\mathrm{CaCl}_{2}$-extractable $\mathrm{Zn}$ concentration in the soil. $\mathrm{Cu}$ concentrations were related to life stages, with higher concentrations in adults. $\mathrm{Pb}$ concentrations were related to the sizes of the animals, with the highest concentrations in the smallest specimens. Significant regressions of metal concentrations in C. glareolus were found for $\mathrm{Zn}$, with the highest concentrations found in the adults trapped in spring at locations with high $\mathrm{CaCl}_{2}$-extractable $\mathrm{Zn}$ concentrations, and for $\mathrm{Cd}$, with the highest concentrations found in the larger animals trapped toward winter. $\mathrm{Cu}$ concentrations in $C$. russula were positively related to $\mathrm{CaCl}_{2}$-extractable concentrations and negatively related to total $\mathrm{Cu}$ concentrations in the soil; they were highest in the larger female animals. Cd concentrations in this species were more closely related to the season (highest toward winter) and were also positively related to $\mathrm{CaCl}_{2}$-extractable concentrations in soil; again, they were highest in female individuals. A significant regression $(P<0.05)$ for $\mathrm{Zn}$ concentrations in $M$. arvalis was only found with the sexes, with the highest concentrations in female animals.

\section{Differences in Population Structure}

Because differences in metal concentrations between species may result from differences in population structure or distribution, the characteristics of each species were analysed. For all species, more adults than juveniles were trapped, but for none of the species was the adults-to-juveniles ratio significantly higher than for another species. The fact that only adults were trapped from two species (C. russula and M. minutus) 

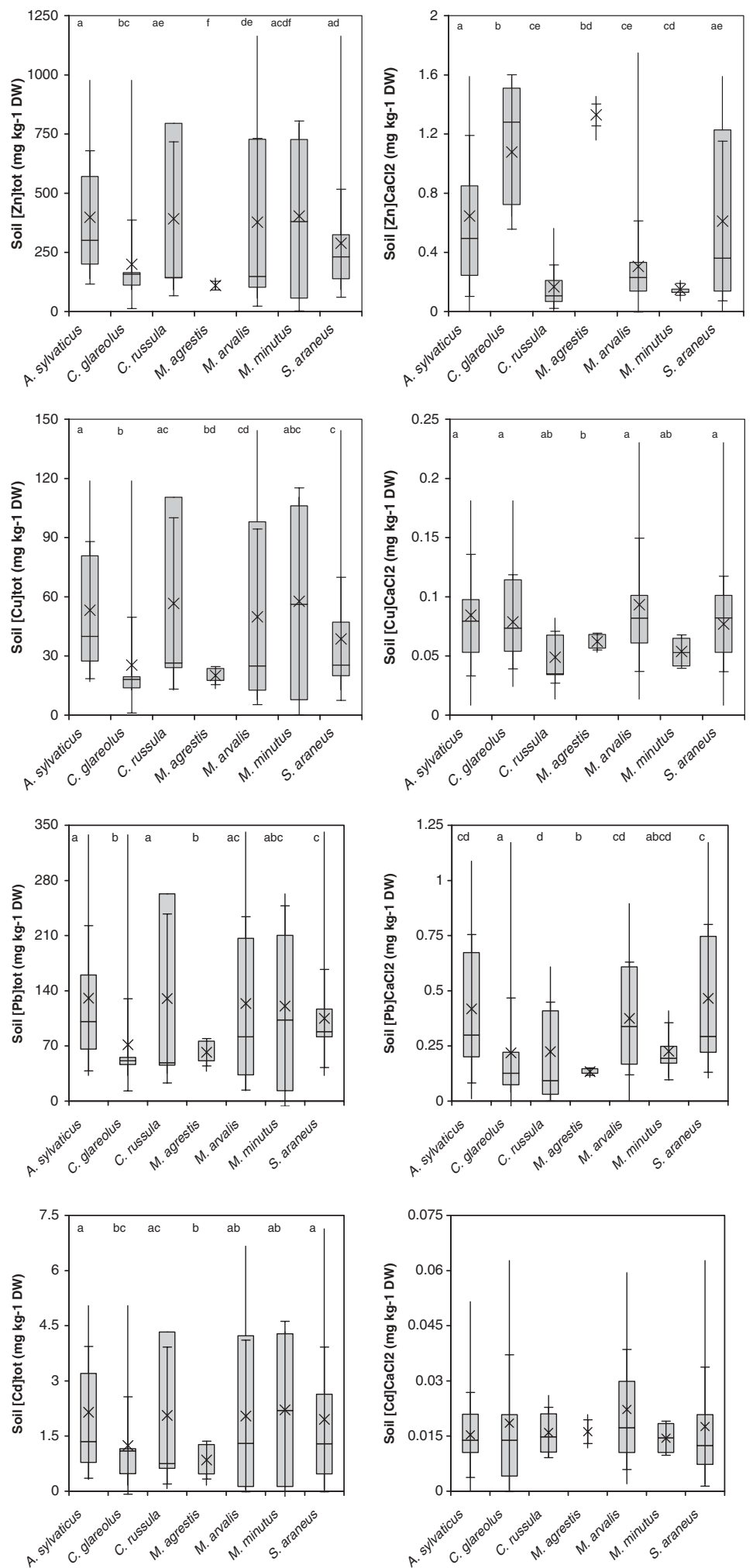

Fig. 3. Total and $\mathrm{CaCl}_{2}$-extractable metal concentrations in the upper $10 \mathrm{~cm}$ of soil at the ADW floodplain area trapping locations. Average metal concentrations are indicated by a cross; error bars show SDs; total range (minimum and maximum observations) is shown as a vertical line. The columns indicate the $25 \%$ and $75 \%$ percentiles, with the median in between. Different letters indicate significant differences $(P<0.05)$ in concentration distributions; identical letters indicate no significant differences between metal concentrations in the soil

was reflected in the FWs of these species, which showed a relatively narrow range, with an $\mathrm{SD}<10 \%$ of the average weight. Comparable numbers of male and female individuals were trapped for nearly all species, except for A. sylvaticus, for which significantly more (i.e., twice as many) male than female animals were trapped. With regard to seasonal differ- ences, $S$. araneus and $C$. glareolus were trapped significantly earlier, because half of those individuals had already been collected in early summer, than A. sylvaticus, of which more individuals were collected throughout fall. S. araneus was trapped earlier than $M$. arvalis, M. agrestis, C. russula, and M. minutus 
Table 3. Significant regressions $(P<0.05)$ between metal concentrations in small-mammal species, characteristics of the species (see Table 1$)$, and environmental variables (critical $F$ value calculated at $P<0.05$ )

\begin{tabular}{|c|c|c|c|c|c|}
\hline Metal & & $F$ & $n$ & $R^{2}$ & $P$ \\
\hline & A. sylvaticus & & & & \\
\hline $\mathrm{Zn}$ & $\ln \left(\left[\mathrm{Zn}_{\text {body }}\right]\right)=1.41($ season $)+0.00107\left(\left[\mathrm{Zn}_{\text {tot }}\right]\right)+1.11($ flood $)-0.722\left(\left[\mathrm{Zn}_{\mathrm{CaCl} 2}\right]\right)-1.24$ & 4.51 & 18 & 0.581 & 0.017 \\
\hline $\mathrm{Cu}$ & $\ln \left(\left[\mathrm{Cu}_{\text {body }}\right]\right)=0.918($ life stage $)-0.490$ & 6.01 & 18 & 0.273 & 0.026 \\
\hline $\mathrm{Pb}$ & $\ln \left(\left[\mathrm{Pb}_{\text {body }}\right]\right)=-0.000610\left(\mathrm{FW}_{\text {body }}\right)+7.30$ & 4.94 & 18 & 0.236 & 0.041 \\
\hline \multirow[t]{2}{*}{$\mathrm{Cd}$} & NS & & 18 & & \\
\hline & C. glareolus & & & & \\
\hline $\mathrm{Zn}$ & $\ln \left(\left[\mathrm{Zn}_{\text {body }}\right]\right)=0.693($ life stage $)-0.554($ season $)+0.295\left(\left[\mathrm{Zn}_{\mathrm{CaCl} 2}\right]\right)+6.58$ & 5.95 & 49 & 0.284 & 0.002 \\
\hline $\mathrm{Cu}$ & NS & & 49 & & \\
\hline $\mathrm{Pb}$ & NS & & 49 & & \\
\hline $\mathrm{Cd}$ & $\begin{array}{l}\ln \left(\left[\mathrm{Cd}_{\text {body }}\right]\right)=0.000236\left(\mathrm{FW}_{\text {body }}\right)+1.48(\text { season })-10.5 \\
\text { C. russula }(s 2, f 1)\end{array}$ & 6.49 & 49 & 0.220 & 0.003 \\
\hline $\mathrm{Zn}$ & NS & & 10 & & \\
\hline $\mathrm{Cu}$ & $\ln \left(\left[\mathrm{Cu}_{\text {body }}\right]\right)=45.1\left([\mathrm{Cu}]_{\mathrm{CaCl} 2}\right)-0.0187\left(\left[\mathrm{Cu}_{\text {tot }}\right]\right)+0.828(\mathrm{sex})+0.000247\left(\mathrm{FW}_{\text {body }}\right)-3.57$ & 19.9 & 10 & 0.941 & 0.003 \\
\hline $\mathrm{Pb}$ & NS & & 10 & & \\
\hline $\mathrm{Cd}$ & $\begin{array}{l}\ln \left(\left[\mathrm{Cd}_{\text {body }}\right]\right)=4.87(\text { season })+199\left([\mathrm{Cd}]_{\mathrm{CaCl} 2}\right)+1.52(\text { sex })-19.2 \\
\text { M. agrestis }\end{array}$ & 17.2 & 10 & 0.896 & 0.002 \\
\hline $\mathrm{Zn}$ & NS & & 8 & & \\
\hline $\mathrm{Cu}$ & NS & & 8 & & \\
\hline $\mathrm{Pb}$ & NS & & 8 & & \\
\hline \multirow[t]{2}{*}{$\mathrm{Cd}$} & NS & & 8 & & \\
\hline & M. arvalis & & & & \\
\hline $\mathrm{Zn}$ & $\ln \left(\left[\mathrm{Zn}_{\text {body }}\right]\right)=0.342(\operatorname{sex})+3.73$ & 4.65 & 29 & 0.147 & 0.040 \\
\hline $\mathrm{Cu}$ & NS & & 29 & & \\
\hline $\mathrm{Pb}$ & NS & & 29 & & \\
\hline \multirow[t]{2}{*}{$\mathrm{Cd}$} & NS & & 29 & & \\
\hline & S. araneus & & & & \\
\hline $\mathrm{Zn}$ & NS & & 45 & & \\
\hline $\mathrm{Cu}$ & NS & & 45 & & \\
\hline $\mathrm{Pb}$ & NS & & 45 & & \\
\hline $\mathrm{Cd}$ & NS & & 45 & & \\
\hline
\end{tabular}

${ }^{a}$ M. minutus is not included because only four animals were trapped. $\left[\mathrm{Me}_{\text {body }}\right]=$ metal concentration in animal $\left(\mathrm{mg} \mathrm{kg}^{-1} \mathrm{DW}\right) . \mathrm{Species}$ characteristics and environmental variables initially included are sex $=1$ for male and 2 for female; life stage $=1$ for juvenile and 2 for adult; $\mathrm{FW}_{\text {body }}=$ fresh weight of animal $(\mathrm{mg}) ;\left[\mathrm{Me}_{\text {tot }}\right]=$ total metal concentration in the soil $\left(\mathrm{mg} \mathrm{kg}^{-1} \mathrm{DW}\right) ;\left[\mathrm{Me}_{\mathrm{CaCl}}\right]=\mathrm{CaCl} 2$-extractable metal concentration in the soil $\left(\mathrm{mg} \mathrm{kg}^{-1} \mathrm{DW}\right)$; flooding $=1$ for flooded and 2 for nonflooded trapping locations; season $=1$ for animals trapped in spring, 2 for summer, 3 for autumn, 4 for winter; ${ }^{\mathrm{s} 2}=$ all animals were adults; ${ }^{\text {; } 1}=$ all animals were trapped in flooded areas; ${ }^{\mathrm{f} 2}=$ all animals were trapped in nonflooded areas. NS = nonsignificant.

With regard to the numbers trapped in flooded and nonflooded areas, significantly $(P<0.05)$ more specimens of C. glareolus and M. agrestis were trapped in nonflooded areas, whereas significantly more specimens of $C$. russula and M. arvalis were trapped in flooded areas.

\section{Discussion}

Differences in average metal concentrations between species can be the result of differences in population structure between the species. The data set also showed differences in the relative numbers of each of the species trapped in each of the seasons. Nevertheless, the trapping results were in accordance with the distribution patterns of the species in the ADW floodplain found during the 2001 and 2002 monitoring programme (Wijnhoven et al. 2006). C. glareolus and S. araneus showed rather stable densities throughout the year. Other species showed density peaks during late summer and autumn. The highest densities of $A$. sylvaticus and M. minutus were found during late autumn and winter. The male-dominated trapping results for A. sylvaticus seem to be a common phenomenon
(Randolph 1977). Kikkawa (1964) suggests that it results from a larger home range size and therefore greater trappability of male individuals.

With regard to the numbers of species trapped in flooded and nonflooded areas, the trapping results of $A$. sylvaticus and $M$. minutus in this study confirm the patterns found earlier by Wijnhoven et al. (2006), with more individuals of these species found in flooded than in nonflooded areas throughout the year. Wijnhoven et al. (2006) also found higher numbers of $M$. arvalis and $C$. russula in flooded areas. Only the fact that the largest proportion of $C$. glareolus was trapped in nonflooded areas is not in agreement with the 2001 and 2002 monitoring results, in which the reverse was found. We collected 56 specimens of $C$. glareolus for this study, which is much more than for most of the other species. This is not in line with the relatively low densities of this species found in 2001 and 2002.

Our measurements of metal concentrations in small-mammal species are representative of the values in the floodplain as a whole, and the previously mentioned differences between the data sets for the various species are generally in line with expectations for the species and the research area. Data for M. minutus should be interpreted with care because only four 
specimens were included in the analyses. C. glareolus might be exposed to different average metal concentrations in years of lower densities or when a larger proportion of the animals is present in the flooded areas. Variable factors-such as the frequency, timing, and duration of flooding and climatic variations and management measures, such as mowing and grazing in the area-can also influence the accumulation risks through effects on habitat suitability and connectivity and therefore on species abundance and distribution.

In accumulation and risk-assessment studies, most attention is given to shrews, in particular $S$. araneus, because these are the small mammals expected to show the highest accumulation of heavy metals in view of their insectivorous and carnivorous diet. However, with regard to the risks of accumulation and possible toxic effects to top predators, vole species are more relevant because they generally occur in much higher densities and are the dominant prey for several species (Jongbloed et al. 1996). In addition, the fact that a particular small-mammal species accumulates larger amounts of heavy metals does not necessarily mean that this is the species most at risk of toxic effects from pollutants. Some species could be more sensitive to heavy metals than others, and storage of heavy metals in organs, such as the liver, could be a good mechanism to cope with toxicants (Shore \& Douben 1994). In our study, $S$. araneus did indeed show the highest heavy-metal concentrations of the seven small mammal species in the ADW floodplain area. For $\mathrm{Cd}$, a maximum difference of a factor of 5.2 was found between $S$. araneus and the vole and mouse species. The differences are not as large as those found in inland areas or as those that have sometimes been suggested. A study by Ma et al. (1991), in polluted and relatively clean inland areas, found that estimated differences, by factors of 26 to 57 , in $\mathrm{Cd}$ intake concentrations resulted in a difference of factors of 46 to 182 in kidney and 83 to 812 in liver concentrations. Hunter et al. (1989) recorded differences of factors of 2.1 to $12.1,8.6$ to 28.2 , and 6.2 to 9.5 in kidney, liver, and muscle tissue, respectively, in control and polluted inland areas. The difference in bioaccumulation of $\mathrm{Cd}$ from soil to $S$. araneus and the voles (Microtidae) is a factor of 32 in the model described by Jongbloed et al. (1996). The estimated difference in exposure risk for shrews and voles, as calculated by Kooistra et al. (2001) for areas in the ADW floodplain, are factors of 2.1 to 9.8 , which is more in line with our findings. For $\mathrm{Pb}$, the difference between $S$. araneus and the vole and mouse species varied between 2.7 and 9.3 in our study. The difference of factors of 6.2 to 11.0 in $\mathrm{Pb}$ intake recorded by $\mathrm{Ma}$ et al. (1991), resulting in a difference of factors of 4.9 to 22.3 in kidney and 1.6 to 7.1 in liver concentrations is in line with our results. However, concentrations of $\mathrm{Pb}$ in $C$. russula and C. glareolus were not significantly different in our study. For $\mathrm{Cu}$, the difference between $S$. araneus and the vole and mouse species varied by factors of 2.2 to 4.6 in our study. These values are similar or even slightly higher than the differences of 1.6 to $2.0,1.6$ to 4.1 , and 1.2 to 1.7 in kidney, liver, and muscle tissue, respectively, as recorded by Hunter et al. (1989). The average $\mathrm{Zn}$ contents in S. araneus in our study did not differ by more than a factor of 2 from those in the Microtine rodent species. In our study, the metal concentrations in, for example, C. glareolus and M. agrestis, did differ less from those in $S$. araneus than recorded in the literature (for $\mathrm{Cu}$ and $\mathrm{Cd}$ ) or were similar to them (for $\mathrm{Zn}$ and $\mathrm{Pb}$ ). In our study, levels, except for $\mathrm{Cd}$, in the shrew $C$. russula were similar to those in $C$. glareolus and also to those in several other vole and mouse species.

We expected that other than differences in metal concentrations between species of different trophic levels, the actual exposure concentrations would be also reflected in the metal concentrations in small-mammal species and individuals (inter and intraspecific variation). Because $C$. glareolus and M. agrestis were predominantly trapped in nonflooded areas, their exposure to total $\mathrm{Zn}$ concentrations in the soil was generally lower than that of the other species, whereas their exposure to $\mathrm{CaCl}_{2}$-extractable $\mathrm{Zn}$ concentrations was higher. This was, however, not reflected in the $\mathrm{Zn}$ concentrations in these two species. This suggests that the accumulation of $\mathrm{Zn}$ in these vole species is not determined by total or by $\mathrm{CaCl}_{2}-$ extractable $\mathrm{Zn}$ fractions alone, indicating that $\mathrm{Zn}$ is regulated by either the food species (Heikens et al. 2001) or by the small mammals themselves (Mertens et al. 2001), which influences observed tissue values. With regard to exposure to $\mathrm{Cu}, \mathrm{Pb}$, and $\mathrm{Cd}$, only exposure to total concentrations was different, i.e., lower for C. glareolus and M. agrestis, than for some of the other species depending on the investigated metal, which was not reflected in the metal concentrations in the species either.

Although exposure concentrations in the soil for $C$. russula were generally similar to those for other species, the metal concentrations show a trend toward concentrations being lower than in $S$. araneus and similar to those in voles. This could be the result of differences in feeding patterns between the two shrew species. Earthworms, which are known to be strong accumulators of heavy metals (Hobbelen et al. 2004; Van Vliet et al. 2005), are more important food items for $S$. araneus than for $C$. russula. It is also possible that macroinvertebrates are more often eaten by vole species, in particular, C. glareolus and $M$. agrestis, than was thought previously.

In addition to the influence of soil metal concentrations for accumulation of heavy metals, several interfering factors might be of importance. For several combinations of small mammal species and metals tested in multiple regressions, no regressions with measured parameters explaining a significant part of the variance $(P<0.05)$ in the observed metal concentrations in the animals were found. For M. agrestis, this can be ascribed to the small sample size and small variance, but also for $S$. araneus, with 45 specimens, no significant regressions were found. None of the parameters were substantially more often found to be related to the metal concentrations in the small mammals. This means that the total metal concentrations in the soil at the trapping location are not a good predictor of the metal concentrations in the small mammals found there. Using $\mathrm{CaCl}_{2}$-extractable concentrations in the soil hardly improved the relation with the accumulated metals in the small mammals. We conclude that the soil metal concentrations at the trapping locations do not necessarily reflect the exposure concentrations throughout the animals' life history. This could be caused by (1) large variations in exposure time (or age of the animals); (2) heterogeneity of the soil concentrations, which means that exposure within an animal's home range may not be similar to that at the trapping location; or (3) movements, dispersal, and/or shifts in feeding patterns, making such correlations irrelevant.

Life-stage and FW of the small mammals only occasionally showed significant regressions. This could reflect a poor 
relationship between FW and age because condition may play a role. $S$. araneus are known to show a decrease in body mass during winter (Ochocińska \& Taylor 2003), which is probably also reflected as a larger variance in tissue-to-total body ratio (Table 2), but such a phenomenon is not assumed for the other species. Life-stage could be a poor predictor because small mammals remain juvenile for only a short period, causing the greatest variation in body metal concentrations within the group of adults. It seems most likely that the poor relations of soil metal concentrations with body metal concentrations result from the migration of species from one area to another or from shifts in diets. However, we found a relationship between the sex and body metal concentrations in three cases, with higher concentrations being found in female than in male individuals, suggesting that there are differences in feeding patterns or home-range structures between the sexes, or pregnancy effects on weight, for $C$. russula and $M$. arvalis.

It is difficult to assess the exposure risk and contaminant levels of individual small mammals in the highly dynamic floodplain environment. However, based on our results, it is nevertheless possible to calculate average risks for species within ecologic units or floodplains as a whole. It is important that the animals collected reflect the species distribution and densities throughout the year, making it crucial to combine measurements of metal accumulation with population monitoring.

Metal concentrations in wild small mammals are often measured in the target organs (e.g., liver and kidneys) (Hunter \& Johnson 1982; Hunter et al. 1984; Ma et al. 1991; Damek-Poprawa \& Sawicka-Kapustra 2003, 2004). Although this is relevant from a toxicologic point of view, total body concentrations may be more relevant when considering small mammals as prey animals. The observed differences in metal concentrations between small-mammal species have consequences for the risks to predators in floodplains. Species preying on S. araneus, for instance, run greater risks of heavy-metal accumulation than species preying on voles and mice. However, S. araneus is generally not the most important prey species for predators (Jongbloed et al. 1996) because the densities of other species are often higher (Wijnhoven et al. 2006). Predators will forage where their preferred prey is available in large numbers, which means that in the ADW floodplain, exposure of predators specialising in bank voles mainly occurs in nonflooded areas, whereas exposure of predators of $M$. arvalis occurs especially in flooded areas. This leads to differences in exposure between predators, such as the weasel (Mustela nivalis) and the Eurasian kestrel (Falco tinnunculus), as a result of their different foraging behaviour (Erlinge et al. 1983), distribution of their prey, and contaminant levels within the prey. During floods, as well as for quite some time after an area has been flooded, exposure of predators of small mammals to heavy metals will generally occur in nonflooded areas. Predators are probably sparse in the area during this time because they are forced to move away because of low prey availability, or, in the case of generalists, forced to prey on other food sources (Van den Brink et al. 2003).

Differences in metal concentration ranges between the small-mammal species seem to be small for $\mathrm{Zn}$, which is probably to a certain extent regulated. Extremely high levels of metals were found in a few individual voles: $\mathrm{Zn}$ and $\mathrm{Pb}$ in C. glareolus, $\mathrm{Cd}$ in M. agrestis, and $\mathrm{Cu}$ in M. arvalis. Although these extreme values could not be directly related to soil concentrations, they can possibly be explained by point sources of pollution and by foraging in other areas than the sample sites alone. All individuals with extreme body concentrations were trapped at or near nonflooded areas. Only in a few cases were the metal concentrations in the mammals related to soil metal concentrations, either total or extractable. We know that this floodplain is diffusely polluted, which implies heterogeneous contamination patterns. However, large differences in contaminant levels over short distances are not to be expected, unless there are certain point sources in the nonflooded areas where industrial activities have taken place in the past' or near the borders between the flooded and nonflooded parts. It is more likely that in this dynamic environment, exposure of small mammals at or near the trapping location only occurs during a part of their life history. Movements and dispersal probably interfere with the relations between soil metal concentrations and the concentrations in the bodies of the mammals. In addition, the metal concentrations in the small mammals could also be affected by shifts in feeding patterns, seasonal and flood-related aspects of food availability, habitat suitability and connectivity, and life-stage-related food preference, combined with the same variations in the metal contents in the food items themselves. Finally, exposure time, and therefore age of the animals, might be an explanatory factor, as was indicated in a few cases by the relation between metal concentrations in small mammals and life stage, FW, or season.

\section{Conclusion}

Heavy-metal concentrations in seven small-mammal species from a diffusely polluted floodplain along the river Rhine differed between species. These differences can be partly explained by the trophic level of the species because metal concentrations were highest in the carnivorous and insectivorous shrew, S. araneus. However, average metal concentrations in $S$. araneus differed from those in the vole and mouse species at the maximum by factors of 2.0, 4.6, 9.3, and 5.2 for $\mathrm{Zn}, \mathrm{Cu}$, $\mathrm{Pb}$, and $\mathrm{Cd}$, respectively, which is less than has been reported by several studies of inland areas. No significant differences were found in average $\mathrm{Zn}, \mathrm{Pb}$, and $\mathrm{Cd}$ concentrations between $S$. araneus, $M$. agrestis, and $C$. russula. The vole $C$. glareolus and the shrew $C$. russula had similar concentrations of $\mathrm{Cu}, \mathrm{Pb}$, and $\mathrm{Zn}$. Although possible differences in accumulation between life-stages and sexes or size- and season-related differences were corrected for, relationships between total or $\mathrm{CaCl}_{2}$ extractable soil metal concentrations at the trapping locations and the metal concentrations in the mammals were poor or absent. We suspect that exposure time, dispersal, and changes in foraging behaviour might be important factors influencing the exposure of small mammals in highly dynamic environments, such as floodplains. The observed differences in metal concentrations between small-mammal species will have consequences in terms of risks to predators in floodplains and should therefore be considered in risk assessments.

Acknowledgments. We thank J. Eygensteyn, L. Pierson, and R. van der Gaag for assistance with ICP analyses; T. Hamers for assistance 
with some of the dissections; M.-J. Verbruggen and M. Stassen for assistance in the laboratory; J. Copius Peereboom-Stegeman for discussing the results; J. Klerkx for linguistic comments; two anonymous reviewers for constructive comments; and the Dutch State Forestry Services (SBB) for permission to conduct research in the ADW floodplain. This research is part of the NWO-SSEO and NWO-LOICZ programmes and is CWE Publication No. 451.

\section{References}

Damek-Poprawa M, Sawicka-Kapusta K (2003) Damage to the liver and testis with reference to burden of heavy metals in yellownecked mice from areas around steelworks and zinc smelter in Poland. Toxicology 186:1-10

Damek-Poprawa M, Sawicka-Kapusta K (2004) Histopathological changes in the liver, kidneys, and testes of bank voles environmentally exposed to heavy metal emissions from the steelworks and zinc smelter in Poland. Environ Res 96:72-78

Dodds-Smith ME, Johnson MS, Thompson DJ (1992) Trace metal accumulation by the shrew Sorex araneus. I. Total body burden, growth, and mortality. Ecotox Environ Safe 24:102-117

Erlinge S, Göransson G, Hansson L, Högstedt G, Liberg O, Nilsson IN et al. (1983) Predation as a regulating factor on small rodent populations in southern Sweden. Oikos 40:36-52

Greville RW, Morgan AJ (1989) Seasonal changes in metal levels $(\mathrm{Cu}, \mathrm{Pb}, \mathrm{Cd}, \mathrm{Zn}$ and $\mathrm{Ca})$ within the Grey field slug, Deroceras reticulatum, living in a highly polluted habitat. Environ Pollut 59:287-303

Heikens A, Peijnenburg WJGM, Hendriks AJ (2001) Bioaccumulation of heavy metals in terrestrial invertebrates. Environ Pollut 113:385-393

Hendriks AJ, Ma W-C, Brouns JJ, De Ruiter-Dijkman EM, Gast R (1995) Modelling and monitoring organochlorine and heavy metal accumulation in soils, earthworms, and shrews in Rhinedelta floodplains. Arch Environ Contam Toxicol 29:115-127

Hobbelen PHF, Koolhaas JE, Van Gestel CAM (2004) Risk assessment of heavy metal pollution for detritivores in floodplain soils in the Biesbosch, the Netherlands, taking bioavailability into account. Environ Pollut 129:409-419

Hunter BA, Johnson MS (1982) Food chain relationships of copper and cadmium in contaminated grassland ecosystems. Oikos $38: 108-117$

Hunter BA, Johnson MS, Thompson DJ (1984) Cadmium induced lesions in tissues of Sorex araneus from metal refinery grasslands. In: Osborn D (ed) Metals in animals. ITE Symposium No. 12, Institiute of Terrestrial Ecology Publications, Monks Wood, Abbots Ripton, MA, pp 39-44

Hunter BA, Johnson MS, Thompson DJ (1989) Ecotoxicology of copper and cadmium in a contaminated grassland ecosystem. IV. Tissue distribution and age accumulation in small mammals. J Appl Ecol 26:89-99

Jongbloed R, Traas TP, Luttik R (1996) A probablistic model for deriving soil quality criteria based on secondary poisoning top predators. II. Calculations for dichlorodiphenyltrichloroethane (DDT) and cadmium. Ecotox Environ Safe 34:279-306

Kikkawa J (1964) Movement, activity and distribution of the small rodents Clethrionomys glareolus and Apodemus sylvaticus in woodland. J Anim Ecol 33:259-299

Klok C, Zorn M, Koolhaas JE, Eijsackers HJP, Van Gestel CAM (2006) Does reproductive plasticity in Lumbricus rubellus improve the recovery of populations in frequently inundated river floodplains? Soil Biol Biochem 38:611-618

Kooistra L, Leuven RSEW, Wehrens R, Buydens LMC, Nienhuis PH (2001) A procedure for incorporating spatial variability in eco- logical risk assessment of Dutch river floodplains. Environ Manage 28:359-373

Kooistra L, Huijbregts MAJ, Ragas AMJ, Wehrens R, Leuven RSEW (2005) Spatial variability and uncertainty in ecological risk assessment: A case study on the potential risk of cadmium for the little owl in a Dutch river flood plain. Environ Sci Technol 39:2177-2187

Leuven RSEW, Wijnhoven S, Kooistra L, De Nooij RJW, Huijbregts MAJ (2005) Toxicological constraints for rehabilitation of riverine habitats: A case study for metal contamination of floodplain soils along the Rhine. Arch Hydrobiol Suppl 155:657-676

Ma W-C, Denneman W, Faber J (1991) Hazardous exposure of ground-living small mammals to cadmium and lead in contaminated terrestrial ecosystems. Arch Environ Contam Toxicol 20:266-270

Mertens J, Luyssaert S, Verbeeren S, Vervaeke P, Lust N (2001) Cd and $\mathrm{Zn}$ concentrations in small mammals and willow leaves on disposal facilities for dredged material. Environ Pollut 115:17-22

Middelkoop H, Van Haselen COG (1999) Twice a river. Rhine and Meuse in the Netherlands. RIZA-Report No 99.003 Arnhem, p 127

Nienhuis PH, Leuven RSEW, Ragas AJM (1998) New concepts for sustainable management of river basins. Backhuys Publishers, Leiden, The Netherlands, p 355

Notten MJM, Oosthoek AJP, Rozema J, Aerts R (2005) Heavy metal concentrations in a soil-plant-snail food chain along a terrestrial soil pollution gradient. Environ Pollut 138:178-190

Ochocińska D, Taylor JRE (2003) Bergmann's rule in shrews: Geographic variation of body size in Palearctic Sorex species. Biol J Linn Soc 78:365-382

Pascoe GA, Blanchet RJ, Linder G (1996) Food chain analysis of exposures and risks to wildlife at a metals-contaminated wetland. Arch Environ Contam Toxicol 30:306-318

Randolph SE (1977) Changing spatial relationships in a population of Apodemus sylvaticus with the onset of breeding. J Anim Ecol 46:653-676

Robinson CT, Tockner K, Ward JV (2002) The fauna of dynamic riverine landscapes. Freshw Biol 47:661-677

Schröder TJ (2005) Uptake of $\mathrm{Cd}, \mathrm{Cu}, \mathrm{Ni}, \mathrm{Pb}$ and $\mathrm{Zn}$ by a variety of plant species in embanked floodplains of the rivers Rhine and Meuse. In: Schröder TJ, (ed) Solid-solution partitioning heavy metals in floodplain soils of the rivers Rhine and Meuse: Field sampling and geochemical modelling. $\mathrm{PhD}$ thesis, Wageningen University, Wageningen, The Netherlands, pp 89105

Shore RF, Douben PET (1994) The ecotoxicological significance of cadmium intake and residues in terrestrial small mammals. Ecotoxicol Environ Safe 29:101-112

Sokal RR, Rohlf FJ (1995) Biometry: The principles and practice of statistics in biological research, 3rd ed. WH Freeman, New York, p 850

Torres KC, Johnson ML (2001) Testing metal bioaccumulation models with measured body burdens in mice. Environ Toxicol Chem 20:2627-2638

Van den Brink NW, Ma W-C (1998) Spatial and temporal trends in levels of trace metals and PCBs in the European badger Meles meles (L., 1758) in The Netherlands: Implications for reproduction. Sci Total Environ 222:107-118

Van den Brink NW, Groen NM, De Jonge J, Bosveld ATC (2003) Ecotoxicological suitability of floodplain habitats in The Netherlands for the little owl (Athene noctua vidalli). Environ Pollut 122:127-134

Van Vliet PCJ, Van der Zee SEATM, Ma W-C (2005) Heavy metal concentrations in soil and earthworms in a floodplain grassland. Environ Pollut 138:505-516 
Vink R, Behrendt H, Salomons W (1999) Development of the heavy metal pollution trends in several European rivers: An analysis of point and diffuse sources. Water Sci Technol 39:215-223

Wijnhoven S, Van der Velde G, Leuven RSEW, Smits AJM (2005)

Flooding ecology of voles, mice and shrews: The importance of geomorphological and vegetational heterogeneity in river floodplains. Acta Theriol 50:453-473

Wijnhoven S, Van der Velde G, Leuven RSEW, Smits AJM (2006) Modelling recolonisation of heterogeneous river floodplains by small mammals. Hydrobiologia 565:135-152 